\title{
Microbial Contamination in Dental Unit Waterlines
}

\author{
Maria Cristina Monteiro de SOUZA-GUGELMIN ${ }^{1}$ \\ Carolina Della Torre LIMA ${ }^{1}$ \\ Sergio Narciso Marques de LIMA ${ }^{2}$ \\ Henis MIAN ${ }^{1}$ \\ Izabel Yoko ITO ${ }^{1}$
${ }^{1}$ Discipline of Microbiology and Immunology, Department of Toxicological and Bromatologic Clinical Analyses, Faculty of Pharmaceutical Sciences of Ribeirão Preto, USP, Ribeirão Preto, SP, Brazil
${ }^{2}$ Discipline of Periodontics, Department of Oral Maxillfacial Surgery and Periodontology, Faculty of Dentistry of Ribeirão Preto, USP, Ribeirão Preto, SP, Brazil

\begin{abstract}
The quality of water in a dental unit is of considerable importance because patients and dental staff are regularly exposed to water and aerosol generated from the dental unit. The aim of this study was to evaluate the occurrence of microbial contamination in dental unit waterlines. Water samples were collected aseptically from the waterlines (reservoir, triple-syringe, high-speed) of 15 dental units. After serial dilution to 1:106 in APHA, the samples were seeded by the pour-plate technique and cultured in plate count agar (Difco) for 48 $\mathrm{h}$ at $32^{\circ} \mathrm{C}$. Analysis was based on the number of colony forming units (CFU). The Wilcoxon non-parametric test indicated that the levels of water contamination were highest in the triple-syringe (13 of 15) and in the high-speed (11 of 15); both levels were higher than those of the water reservoir. There was no significant statistical difference between the level of contamination in the triple-syringe and the high-speed as determined by the Mann-Whitney test $[\mathrm{p}(\mathrm{H} 0)=40.98 \% ; \mathrm{Z}=-0.2281]$. Because biofilm forms on solid surfaces constantly bathed by liquid where microorganisms are present, these results indicate that the water in the dental unit may be contaminated by biofilm that forms in these tubules.
\end{abstract}

Key Words: dental unit waterline, microbial contamination, biofilm.

\section{INTRODUCTION}

Infection control is of major importance in routine daily procedures of a dental office. According to Ito et al. (1), a series of actions, anti-sepsis, laying of

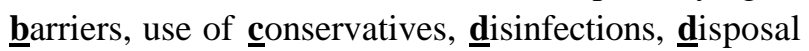
and sterilization (ABCDDS) could considerably reduce the risk of cross-infection in dentistry. This should be considered as important as hospital cross-contamination. There is no doubt that exposure of the dental staff and patients to high levels of microbial contamination leads to a high risk of infection $(2,3)$. For effective infection control, every possible source of contamination should be submitted to ABCDDS actions before, during and after dental intervention.

Concerns over dental unit waterlines (DUWL) as a source of infection is recent (4-6) Notwithstanding the lack of epidemiological evidence, at the level of public health, pathogens potentially harmful to hu- mans, such as Pseudomonas (2,7), Legionella (8) and some strains of Mycobacterium (9) have been isolated from dental unit waterlines. According to Murdochkinch (10), contamination due to biofilm in waterlines is a recent concern that should be considered and included in the control of infection in dental offices. According to Mills (11), microorganisms from biofilm that colonize DUWLs contaminate the water that is used in dental treatment and consequently, the high level of microbial contamination found in these units violates basic infection control principles.

Thus, the objective of this study was to determine the occurrence of microbial contamination in dental unit waterlines (reservoir, triple-syringe and highspeed) in dental offices.

\section{MATERIAL AND METHODS}

Samples of waterlines (reservoir, triple-syringe 
and high-speed equipment) of 15 dental units from private dental clinics in Ribeirão Preto (SP, Brazil) were collected aseptically. Samples were taken to the Laboratory of Microbiology of the Faculty of Pharmaceutical Sciences, and processed immediately.

The water samples were serially diluted in APHA (eluent provided by the American Public Health Association (12), composition: $34 \mathrm{~g}$ monobasic phosphate and $1000 \mathrm{ml}$ distilled water) from $1: 10$ to $1: 10^{6}$ and seeded by the pour-plate technique. For this, $1.0 \mathrm{ml}$ aliquots of water were deposited at the center of sterile empty Petri dishes, followed by $19.0 \mathrm{ml}$ of plate count agar (Difco, Sparks, MD, USA). After homogenization and solidification of the mixture, the plates, in duplicate for all samples, were incubated for $48 \mathrm{~h}$ at $32^{\circ} \mathrm{C}$. The number of colony forming units (CFU) was determined in each plate after incubation and the $\mathrm{CFU} / \mathrm{ml}$ of water was calculated by number of colonies $\mathrm{x}$ dilution factor. The values for each dilution per sample were added and the arithmetic mean determined.

Statistical analysis of the results was made by the Wilcoxon test. In this case, the test was utilized to measure significance in the increase of contamination in the water of both the triple-syringe and the highspeed in relation to the initial contamination of the

Table 1. Levels of microbial contamination of the water in the reservoir, triple-syringe and high-speed of 15 dental units.

\begin{tabular}{rrrr}
\hline & \multicolumn{3}{c}{ Average number of aerobic organisms } \\
& \multicolumn{3}{c}{$(\mathrm{CFU} / \mathrm{ml})$} \\
\cline { 2 - 4 } Dental units & Reservoir & Triple-syringe & High-speed \\
\hline 1 & 282 & 46,750 & $1,280,000$ \\
2 & 1,215 & 99,750 & 195,834 \\
3 & 23,350 & 137,000 & 502,500 \\
4 & 28 & 81,500 & 190 \\
5 & $1,330,000$ & $5,900,000$ & 108,500 \\
6 & 35,000 & $300,000,000$ & $300,000,000$ \\
7 & 101,000 & 301,000 & 61 \\
8 & 0 & 375,000 & 0 \\
9 & 10,800 & 300,000 & $190,000,000$ \\
10 & $1,520,000$ & 267,667 & $1,470,000$ \\
11 & 116,500 & $1,450,000$ & 133,000 \\
12 & 6,300 & 525,000 & $1,515,000$ \\
13 & 0 & 0 & 173,334 \\
14 & 206,500 & $1,473,333$ & $1,520,000$ \\
15 & 15 & $1,121,667$ & $1,710,000$ \\
\hline
\end{tabular}

reservoir. The Mann-Whitney, non-parametric test was also used to determine the significance of the differences in the increase of contamination in water samples from the triple-syringe and the high-speed.

\section{RESULTS}

The quantitative microbiological analysis of samples collected in waterlines of 15 dental units indicated that 13 of 15 reservoirs were contaminated to different extent and that samples from the triple-syringe (13 of 15) and from the high-speed (11 of 15) showed an increase in relation to the corresponding reservoir considered here as the initial contamination. Table 1 shows the results in $\mathrm{CFU} / \mathrm{ml}$ of water for different segments of the waterlines.

Analysis of the data in Table 1 by the Wilcoxon test indicated that the levels of contamination of the samples from the high-speed $[\mathrm{p}(\mathrm{H} 0)=0.38 \%$ for $\mathrm{Z}=$ 2.67] and of the samples of the triple-syringe $[\mathrm{p}(\mathrm{H} 0)=$ $0.09 \%$ for $Z=3.11]$ were significantly higher $(\alpha=0.01)$ than the initial contamination detected in the reservoirs. Analysis of the data by the Mann-Whitney test indicated that there was no significant difference between the levels of contamination of the water samples from the high-speed and those from the triple-syringe [ $\mathrm{p}(\mathrm{H} 0)$ $=40.98 \%$ for $\mathrm{Z}=-0.2281]$.

\section{DISCUSSION}

Biofilm can be considered to be communities of cooperation between microorganisms. The presence of biofilm in DUWLs indicates that the formation of biofilm is a universal problem and that pathogens from patients and the dental clinic environment can be cultivated from biofilm removed from DUWLs (6).

The high level of contamination of waterlines feeding dental units demonstrated in this study confirms the results of others (3,13-15). Several methods of reducing the level of contamination in dental unit waterlines have been proposed, one of them being the use of a separate supply line independent of the main line serving the Clinic. According to Fayle and Pollard (16) and Panagakos et al. (17), this system has advantages because it allows the association of biocides and of protocols to maintain water free from contamination.

In this study, the reservoirs of the dental units were supplied with distilled water, which although not 
sterile, had low levels of contamination, as can be seen in Table 1. However, the use of water with an initial low contamination level did not prevent its increase by the time it reached the patient's mouth and the general environment of the office, as indicated by the levels of contamination of the high-speed and the triple-syringe. Thus, besides independent reservoirs, it is necessary to develop methods to reduce or eliminate biofilm coating the internal walls of the tubules in the system.

We agree with Putnins et al. (4) who reported that DUWL contamination is an increasing concern in the dental clinic because of the risk to the health of the patient, especially because the bacterial count in the water from these units increases with the formation of biofilm in its interior

Thus, the present investigation shows that the DUWL is an important source of cross-infection in dental offices. Further studies evaluating biosecurity measures to prevent the dissemination of this type of contamination are needed.

\section{RESUMO}

A qualidade microbiológica da água do equipo odontológico é de extrema importância, uma vez que os pacientes e a equipe odontológica estão frequientemente expostos à água e aos aerossóis gerados pelo alta-rotação e pela seringa-tríplice. Assim, o objetivo deste trabalho foi o de demonstrar a ocorrência de contaminação microbiana na linha de água de equipos odontológicos, em virtude da formação de biofilme microbiano nas tubulações destes. As amostras de água foram colhidas assepticamente, a partir da linha de água (reservatório, seringa-tríplice e altarotação) de cada um dos 15 equipos odontológicos analisados. As amostras foram diluídas e semeadas em Plate Count Agar (Difco) pela técnica de pour-plate. Estas placas foram incubadas em aerobiose, a $32^{\circ} \mathrm{C}$, por 48 horas. Decorrido este período, o número total de unidades formadoras de colônia foi determinado. Verificou-se pela aplicação do teste de Wilcoxon, que o nível de contaminação das amostras de água, recuperada tanto a partir do alta-rotação como da seringa-tríplice, era significativamente maior que o nível de contaminação inicial da água, verificada no reservatório. Este significante aumento do nível de contaminação da água do alta-rotação e da seringa-tríplice, em relação à contaminação inicial verificada na água do reservatório ocorreu, respectivamente, em 11 e em 13 dos 15 equipos odontológicos analisados. Pôde-se ainda verificar, por meio do teste de MannWhitnney que não havia diferença estatisticamente significante $(\mathrm{p}(\mathrm{H} 0)=40,98 \%$, para $\mathrm{Z}=-0,2281)$ entre o nível de contaminação das amostras colhidas a partir do alta-rotação e da seringa- tríplice. Com base nos resultados obtidos, pôde-se concluir que a água do equipo odontológico, possivelmente, seja contaminada pelo biofilme microbiano, que com o passar do tempo, se forma em suas tubulações, uma vez que é sabido que, o biofilme se forma onde estejam presentes microrganismos e superfície sólida, constantemente banhada por líquido.

\section{REFERENCES}

1. Ito, IY, Souza-Gugelmin MCM, Lima, SNM. Assepsia e antisepsia em endodontia. Biossegurança: controle de infecção. In: Endodontia. Tratamento de canais radiculares. Leonardo MR, Leal JM. ed. 3rd ed. São Paulo: Panamericana. 1998. p. 261-297

2. Williams JF, Johnston AM, Johnson B, Huntington MK, Mackenzie CD. Microbiological contamination of dental unit waterlines; prevalence, intensity and microbial characteristics. J Am Dent Assoc 1993;124:59-65.

3. Meiller TF, Kelley JI, Baqui AA, DePaola LG. Disinfection of dental unit waterlines with an oral antiseptic. J Clin Dent 2000;11:11-15.

4. Putnins EE, Di Giovanni D, Bhullar AS. Dental unit waterline contamination and its possible implications during periodontal surgery. J Periodontol 2001;72:393-400.

5. Meiller TF, Kelley JI, Baqui AA, DePaola LG. Laboratory evaluation of anti-biofilm agents for use in dental unit waterlines. J Clin Dent 2001;12:97-103.

6. Pederson ED, Stone ME, Ragain JC, Simecek JW. Waterline biofilm and the dental treatment facility: a review. Gen Dent 2002;50:190-195.

7. Costerton JW, Cheng KJ, Geesey GG. Bacterial biofilms in nature and disease. Ann Rev Microbiol 1987;41:435-464.

8. Reinthaler F, Mascher F. Legionella pneumophilia in dental units. Zentrallbl Bakteriol Microbiol Hyg [B] 1986;183:86-88.

9. Schulze-Robeke R, Janning B, Fischede R. Occurrence of mycobacteria in biofilm samples. Tuber Lung Dis 1992;73:141-144.

10. Murdochkinch CA. Comparison of dental water quality management procedures. J Am Dent Assoc 1997;128:1235-1243.

11. Mills SE The dental unit waterline controversy: defusing the myths, defining the solutions. J Am Dent Assoc 2000;131:1427-1441

12. American Public Health Association. Standard Methods for the Examination of Water and Wastewater. 11th ed. New York. 1960.

13. Gross A, Devine MJ, Cutright DE. Microbial contamination of dental units and ultrasonic scalers. J Periodontal 1976;47:670673.

14. Barbeau J, Tanguay R, Faucher E. Multiparametric analysis of waterline contamination in dental unit water. J Dent 1996;62:3954-3959.

15. Linger JB, Molinari JÁ, Forbes WC, Farthing CF, Winget WJ Evaluation of a hydrogen peroxide disinfectant for dental unit waterlines. 2001;132:1287-1291.

16. Fayle AS, Pollard MA. Decontamination of dental unit water systems: a review of current recommendations. Br Dental J 1996;181:369-372.

17. Panagakos FS, Lassiter T, Kumar E. Dental unit waterlines: review and product evaluation. 2001;72:20-25.

Accepted July 22, 2002 